\title{
THE EFFECT OF TEMPERATURE ON EMERGENCE OF APPLE LEAF CURLING MIDGE AND ITS PARASITOID PLATYGASTER DEMADES
}

\author{
W.R.M. SANDANAYAKA ${ }^{1}$ and P.W. SHAW ${ }^{2}$ \\ ${ }^{1}$ HortResearch, Private Bag 92169, Auckland, New Zealand \\ ${ }^{2}$ HortResearch, PO Box 220, Motueka, New Zealand \\ Corresponding author: msandanayaka@hortresearch.co.nz
}

\begin{abstract}
Effect of soil temperature on emergence of apple leaf curling midge (ALCM) and its parasitoid, $P$. demades, was studied in the laboratory. Apple leaves infected with $1^{\text {st }}$ and $3^{\text {rd }}$ generation ALCM larvae were collected from Auckland, Nelson and Hawke's Bay in November 2004 and January 2005. In the laboratory, larvae were reared in boxes with a layer of potting mix at five constant temperatures $\left(11,15,19,23\right.$ and $\left.27^{\circ} \mathrm{C}\right)$, and daily numbers of ALCM and P. demades adults that emerged in 2 nd and 4 th generations were recorded. Emergence patterns and rates of emergence for both insect species at the five temperatures were compared across two generations and three locations. Levels of parasitism varied among samples but more parasitoids emerged at $19^{\circ} \mathrm{C}$ for both generations. Development time of the pupae for both insect species was influenced by temperature but $P$. demades took a longer period to develop at lower temperatures than ALCM, resulting in longer intervals between ALCM and P. demades emergence. Results suggest that soil temperature has an impact on the lack of synchrony of 2nd generation emergence between ALCM and P. demades primarily in the spring when soil temperature in most areas is below $15^{\circ} \mathrm{C}$.
\end{abstract}

\section{STICKY TRAPS FOR MONITORING BENEFICIAL INSECTS IN PIPFRUIT ORCHARDS}

\author{
D.R. WALLIS and P.W. SHAW \\ HortResearch, Old Mill Rd, RD 3, PO Box 220, Motueka, New Zealand \\ Corresponding author: rwallis@hortresearch.co.nz
}

Biological control of apple pests is an important aspect of integrated fruit production (IFP). Sticky traps provide a useful tool for monitoring activity of important beneficial insects. Beneficial insects within a block of disease resistant apples have been monitored for four seasons, from 2001-02 until 2004-05, using a 190 x 180 mm single-sided sticky trap. The sticky trap has been mounted on the same tree in the block for all seasons with the base being replaced weekly or fortnightly throughout each growing season (September to April). Key beneficial insects monitored included Platygaster demades, Aphelinus mali and Encarsia pernicioi, which are parasitoids of the important pipfruit pests, apple leaf curling midge (Dasyneura mali), woolly apple aphid (Eriosoma lanigerum) and San Jose scale (Quadraspidiotus perniciosus) respectively. The aim of this work is to monitor the long term potential for biological control of pest populations in the absence of disruptive pesticides. 